\title{
MILK YIELD AND COMPOSITION OF CHIOS AND FARAFRA SHEEP UNDER SUBTROPICAL EGYPTIAN CONDITIONS
}

\author{
H. Hamdon ${ }^{1}$, M.N. Abd El Ati ${ }^{2}$, M. Zenhom ${ }^{3}$ and F. Allam ${ }^{2}$ \\ 1-Environmental Studies and Research Institute, University of Minufiya, Sadat, \\ Egypt, 2- Department of Animal and Poultry Production, Faculty of Agriculture, \\ University of Assiut, Egypt, 3- Department of Sheep and Goats Research, Animal \\ Production Research Institute, Giza, Egypt
}

\section{SUMMARY}

Means of 176 ewes (135 Farafra and 40 Chios) daily milk yield (DMY), milk yield pre-weaning $(M B W)$, milk yield post-weaning $(M A W)$, total milk yield (TMY) and lactation length (LL) for Chios ewes were 0.703, 49.9, 16.8, $66.7 \mathrm{~kg}$ in 96 days, while for Farafra ewes mean were 0.675, 46.0, 13.4, $59.4 \mathrm{~kg}$ in 88 days, respectively. Breed differences were significant $(P<0.01)$ in $T M Y$ and $L L$. Ewes rearing twin lambs produced significantly $(P<0.01)$ more milk than those rearing single lambs. Ewes lambing in the spring had greater milk yield compared to ewes lambing in summer and autumn. Ewes $>4-\leq 5$ years of age showed relatively higher milk yield than younger or older ones. Fat\% of 36 ewes (18 Farafra and 18 Chios) averaged 6.17 for Chios which was significantly $(P<0.01)$ higher than 5.59\% for Farafra. Also, Chios had slightly higher TS\% than Farafra (16.04\% vs. 15.59\%), respectively. Protein content for Chios and Farafra milk differed significantly $(P<0.01)$ and averaged $5.62 \%$ and $5.31 \%$, respectively. Chios ewes had higher milk energy (4.59 MJ/kg) than Farafra (4.34 MJ/kg). The autumn lambing ewes had a significantly higher fat $\%, T S \%$ and milk energy (MJ/kg) than either summer or spring lambing season.

\section{Keywords: Milk, yield, composition, Chios, Farafra}

\section{INTRODUCTION}

Sheep represent an important part of the agricultural economy of Egypt with an estimated 4,672,000 heads. In Egypt, sheep are non-dairy, but produce 93,000 ton milk yearly (FAO, 2004). A new demand on sheep milk cheese is developing either due to the increased tourism or to changing consumers performance. Moreover, production is the base for good lamb performance. In Egypt, the potentiality of the local breeds of sheep or milk production is not clearly identified (Galal et al., 2002). The aim of this study was to evaluate milk yield and composition of Chios and Farafra sheep.

\section{MATERIALS AND METHODS}

A Chios flock was imported by the Ministry of Agriculture at the end of 1986, the Farafra flock was introduced to Mallawi Research Station in 1992. Farafra is a local

Issued by The Egyptian Society of Animal Production 
sheep dominant in El-Farafra Oasis of the Egyptian western desert, New valley. The sheep flock was managed under an accelerated lambing system that permits the ewe to lamb three times each two years. Thus, three breeding and three lambing seasons were as follows:

\begin{tabular}{lcc}
\hline Mating season & Lambing season & Weaning \\
\hline January & June & August \\
September & February & April \\
May & October & December \\
\hline
\end{tabular}

At lambing, new born lambs were ear tagged and weight the day after birth. All the first three days, newborn lambs were kept with their mothers in lambing pens. Dams were weighed on the $4^{\text {th }}$ day after parturition. Lambs were kept with their dams till weaning at 8 weeks and gradually fed starter [ $83 \%$ yellow corn, $15 \%$ Soya bean meal, $1.4 \%$ ground limestone $(\mathrm{CaCO} 3), 0.5 \%$ salt $(\mathrm{NaCl})$ and $0.1 \%$ vitamins and minerals mixture] and Egyptian clover (barseem, Trifolium Alexandrinum) hay gradually until 4 months of age.

Animals were housed by breed in semi-open pens, sheared twice a year, in March and September, drinking water was available twice daily during winter and three times during summer and mineral blocks were available at all the time.

Animals were fed according to recommendation of APRI (2000). During winter, the animals graze Egyptian clover from December to May. During summer months they grazed crop residues or green fodder. Pelleted concentrate mixture $(0.5$ to 1.0 $\mathrm{kg} /$ head/day) was provided according to their physiological status plus clover hay or wheat straw. Ewes were supplemented with concentration feeding of about 0.250 $\mathrm{kg} /$ head two weeks prior to mating season for flushing and also during the last two to four weeks of pregnancy and first week of lactation.

Milk yield was measured on 176 ewes (135 Farafra and 40 Chios). Ewes measured were selected after one week parturition in three lambing seasons. Milk yield was estimated by the lamb suckling weight differential technique (Economides, 1987). After the 8th week, lambs were weaned and ewes were hand milked twice daily at 7 am and at $17 \mathrm{pm}$. Milk samples of 36 ewes (18 Farafra and 18 Chios) were taken every two weeks throughout the lactation period from 12 ewes in the three seasons, for chemical analysis.

Data were analyzed statistically using the GLM procedure, LSM, (SAS, 1995), and Duncan's multiple range test (Duncan, 1955).

Data of milk yield were analyzed using the following model:

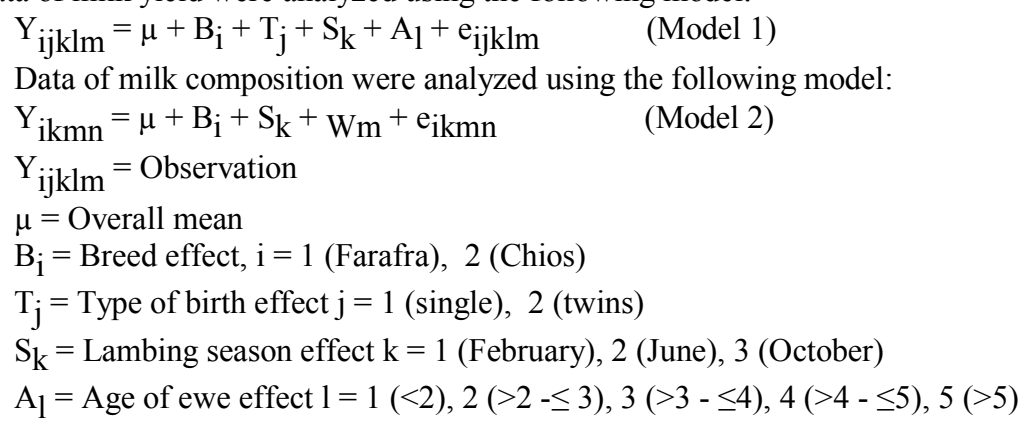




$$
\begin{aligned}
& \mathrm{E}_{\mathrm{ijklm}}=\text { Error } \\
& \mathrm{Wm}=\text { Lactation weeks effect } \mathrm{m}=1(\mathrm{~W} 2), \ldots . .9(\mathrm{~W} 18) \\
& \mathrm{E}_{\mathrm{ikmn}}=\text { Error }
\end{aligned}
$$

\section{RESULTS AND DISCUSSION}

\section{Milk yield}

1. Breed effect: Means for Farafra ewes were 0.675, 46.0, 13.4, $59.4 \mathrm{~kg}$ and 88 days, for DMY, MBW, MAW, TMY and LL, respectively. While, the estimates for Chios ewes were $0.703,49.9,16.8,66.7 \mathrm{~kg}$ and 96 days, respectively. Breed differences were significant $(\mathrm{P}<0.01 \& 0.5)$ for TMY, MBW, MAW and LL (Table, 1). The present figure of Chios was lower than that reported by Mousa (1991) who found TMY, MBW and LL were 143.2, $103.6 \mathrm{~kg}$ and 142 days, respectively. These results may be attributed to inbreeding in Chios flock and that nutritional recommendations according to APRI (2000) were not suitable. Moreover, the better performance of Farafra ewes could be due to more adaptation to Egyptian subtropical conditions as compared to exotic Chios. Lactation curves are presented in Figure (1). Farafra and Chios ewes reached maximum yield at the second week of lactation $[7.95 \mathrm{~kg} /$ week $(1.13 \mathrm{~kg} /$ day $)$ and $8.38 \mathrm{~kg} /$ week $(1.19 \mathrm{~kg} /$ day $)]$, after attaining the peak at the second week of lactation, milk yield decreased gradually till the end of lactation period.

\begin{tabular}{|c|c|c|c|c|c|c|}
\hline Items & $\mathbf{N}$ & DMY/g & MBW/kg & MAW/kg & TMY/kg & LL/day \\
\hline G. mean & 176 & $0.634 \pm 0.13$ & $43.10 \pm 8.78$ & $12.62 \pm 5.34$ & $55.72 \pm 11.67$ & $87.97 \pm 10.94$ \\
\hline \multicolumn{3}{|c|}{ Breed effect } & $*$ & $* *$ & $* *$ & $* *$ \\
\hline Farafra & 136 & $0.675 \pm 0.01$ & $45.96 \pm 0.88$ & $13.43 \pm 0.54$ & $59.40 \pm 1.18$ & $87.93 \pm 1.10$ \\
\hline Chios & 40 & $0.703 \pm 0.02$ & $49.90 \pm 1.66$ & $16.77 \pm 1.01$ & $66.67 \pm 2.21$ & $96.15 \pm 2.07$ \\
\hline \multicolumn{2}{|c|}{ Type of birth } & $* *$ & ** & $* *$ & $* *$ & $* *$ \\
\hline Single & 133 & $0.614 \pm 0.01$ & $41.53 \pm 0.96$ & $11.07 \pm 0.58$ & $52.60 \pm 1.28$ & $86.10 \pm 1.20$ \\
\hline Twins & 43 & $0.764 \pm 0.02$ & $54.33 \pm 1.59$ & $19.13 \pm 0.96$ & $73.47 \pm 2.11$ & $97.98 \pm 1.98$ \\
\hline $\begin{array}{l}\text { Lambing } \\
\text { season }\end{array}$ & & $* *$ & $* *$ & $* *$ & $* *$ & ** \\
\hline February & 72 & $0.736 \pm 0.02^{\mathrm{a}}$ & $51.60 \pm 1.25^{\mathrm{a}}$ & $17.91 \pm 0.76^{\mathrm{a}}$ & $69.50 \pm 1.66^{\mathrm{a}}$ & $95.29 \pm 1.56^{\mathrm{a}}$ \\
\hline June & 45 & $0.721 \pm 0.03^{\mathrm{a}}$ & $48.54 \pm 1.99^{\mathrm{b}}$ & $12.62 \pm 1.21^{\mathrm{b}}$ & $61.15 \pm 2.66^{b}$ & $84.72 \pm 2.49^{b}$ \\
\hline October & 59 & $0.610 \pm 0.02^{b}$ & $43.66 \pm 1.48^{b}$ & $14.78 \pm 0.09^{\mathrm{a}}$ & $58.45 \pm 1.97^{b}$ & $96.10 \pm 1.85^{\mathrm{a}}$ \\
\hline \multicolumn{2}{|c|}{ Age of ewe } & $* *$ & $*$ & & & \\
\hline$<2$ & 40 & $0.638 \pm 0.02^{\mathrm{c}}$ & $44.83 \pm 1.71^{\mathrm{c}}$ & $14.83 \pm 1.04^{\mathrm{b}}$ & $59.67 \pm 2.27^{\mathrm{ab}}$ & $93.06 \pm 2.13^{\mathrm{a}}$ \\
\hline$>2-\leq 3$ & 36 & $0.686 \pm 0.02^{b c}$ & $47.08 \pm 1.70^{\mathrm{bc}}$ & $16.12 \pm 1.03^{\mathrm{a}}$ & $63.20 \pm 2.26^{\mathrm{b}}$ & $93.42 \pm 2.12^{\mathrm{a}}$ \\
\hline$>3-\leq 4$ & 21 & $0.721 \pm 0.03^{b}$ & $50.88 \pm 2.07^{\mathrm{a}}$ & $13.58 \pm 1.27^{\mathrm{b}}$ & $64.46 \pm 2.75^{\mathrm{a}}$ & $98.95 \pm 2.58^{\mathrm{a}}$ \\
\hline$>4-\leq 5$ & 24 & $0.741 \pm 0.03^{\mathrm{a}}$ & $50.79 \pm 2.02^{\mathrm{b}}$ & $15.76 \pm 1.23^{\mathrm{ab}}$ & $66.55 \pm 2.69^{\mathrm{a}}$ & $90.55 \pm 2.52^{\mathrm{a}}$ \\
\hline$>5$ & 55 & $0.659 \pm 0.02^{\mathrm{bc}}$ & $46.07 \pm 1.36^{\mathrm{bc}}$ & $15.23 \pm 0.83^{\mathrm{ab}}$ & $61.30 \pm 1.81^{\mathrm{ab}}$ & $93.20 \pm 1.70^{\mathrm{a}}$ \\
\hline
\end{tabular}

Table 1. LSM \pm SE of factors affecting milk yield $(\mathrm{kg})$ at different stages and lactation length 


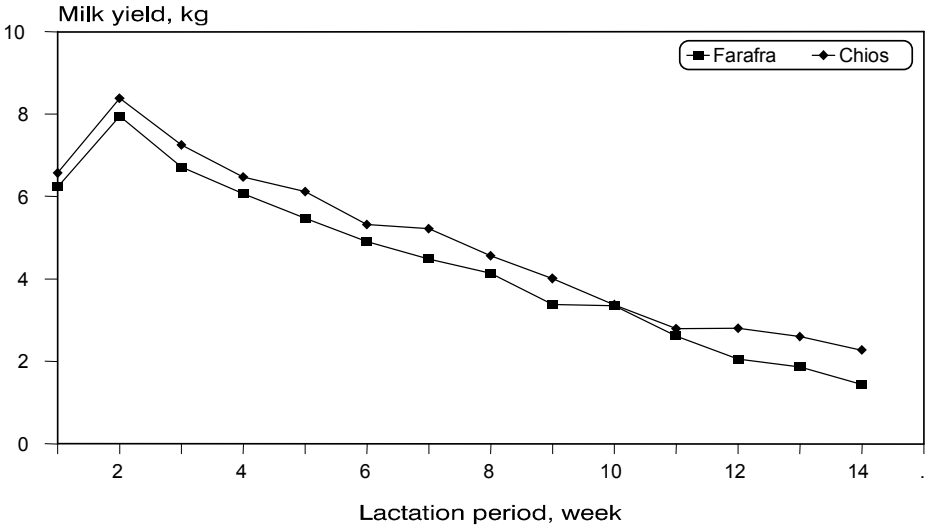

Fig. 1. Lactation curves of Farafar and Chios ewes

2. Lambing season: Ewes that lambed in the spring season (February $-9.5 \mathrm{~kg}$ ) had greater milk yield compared to ewes lambing in the summer season (June $-1.2 \mathrm{~kg}$ ) and autumn season (October $-8.5 \mathrm{~kg}$ ) Seasonal differences had a highly significant effect $(\mathrm{P}<0.01)$ on both milk yield and lactation length as shown in Table (1). Ewes lambing in spring season had a longer lactation length than those lambed at summer (June) season. Ewes lambing the spring, showed more persistency in their weakly milk yield which resulted in higher total milk production than both summer or autumn lambed ewes. Milk yield of the spring season declined steadily after the peak of lactation (at the $2^{\text {nd }}$ week of lactation), while summer or autumn season declined sharply after it peak (Figure 2). Seasonal variation could be attributed mainly to nutritional and husbandry, i.e. availability of green fodder in addition to possible effect of the ambient environmental conditions. Ewes lambed during spring season (February) were fed green fodder during late pregnancy period and the whole lactation period. Also, Aboul-Naga et al. (1981) found that milk yield during spring season (February) was significantly higher than those lambed during autumn (October) or Summer (May) seasons.

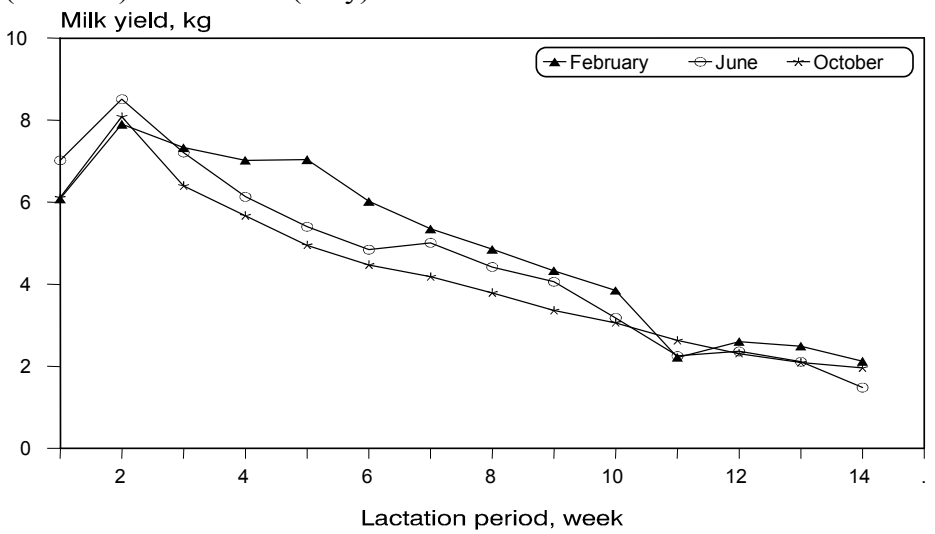

Fig. 2. Lactation curves of February, June and October season 
3. Type of birth: Ewes rearing single lambs had $0.614,41.5,11.1,52.6 \mathrm{~kg}$ and 86 days of DMY, MBW, MAW, TMY and LL, respectively (Table, 1), while ewes rearing twin lambs had $0.764,54.3,19.1,73.5 \mathrm{~kg}$ and 98 days, respectively. Average DMY, MBW and TMY increased by $24.4,30.8$ and $39.7 \%$ in ewes suckling twin lambs compared to those suckling single lambs, respectively. The differences due to number of suckling lambs were significant $(\mathrm{P}<0.01)$ at each stage of lactation and lactation length (Table 1). Ewes suckling twins produced more milk $(\mathrm{P}<0.01)$ than those suckling single lambs at each stage of lactation. This phenomenon is attributed to the ability of twin lambs to empty more completely the udder of their dams and to the more frequent suckling times applied to mammary glands by twins than single lambs. Milk yield of ewes rearing single or twins lambs increased with advancing of lactation period till it reached a peak at the second week then, it decreased gradually till the end of lactation period. Similar, results were reported by Aboul-Naga et al. (1981) who found that differences due to number of suckling lambs were highly significant in Rahmani ewes. Also, Hassan (1995) indicated that ewes rearing twins produced ore milk $(74.8 \mathrm{~kg})$ than those suckling single lambs $(71.2 \mathrm{~kg})$, during 138 days and 136 days, respectively.

4. Age of ewe: Ewes of $(>4-\leq 5)$ year old had relatively higher milk yield than younger or older ones (Table 1) Total milk yield of the fourth group $(>4-\leq 5)$ years was the highest $(66.6 \mathrm{~kg})$ in spite of the shortest lactation period They reach the maximum of lactation during this age. While, the first group $(<2)$ years gave the lowest amount $59.7 \mathrm{~kg}$, but age of ewe at lambing non-significantly affected TMY, MAW and LL, while it was significant $(\mathrm{P}<0.01)$ for average DMY and significant $(\mathrm{P}<0.05)$ for MBW. Generally, average milk yield increased with increase in age of ewe. Aboul Naga et al. (1981) and Hassan (1995) noticed that age of ewe had no significant effect on milk yield.

5. Weight of ewe: Correlation coefficients between weight of ewes at lambing and each of average DMY, MBW, MAW and LL were positive and highly significant $(\mathrm{P}<0.01)$. These results are in agreement with Al-Saigh and Al-Khauzai (1991 \& 1993).

6. Lamb birth weight: A positive and highly significant correlation $(\mathrm{P}<0.01)$ was found between birth weight of lambs and each of average DMY, MBW, MAW, TMY and LL. These results confirmed that the heavier lambs showed a good ability to stimulate their dams to produce more milk particularly during their early life. Also, Al-Saigh and Al-Khauzai (1993) found that the correlation coefficients and the linear regressions between lambs birth weights and their dams milk yield were highly significant.

\section{Milk composition}

1. Breed effect: Fat $\%$ averaged $6.17 \%$ for Chios and was significantly $(\mathrm{P}<0.01)$ higher than $5.59 \%$ for Farafra milk (Table 2). Fat\% increased gradually with advancing stage of lactation until the end of the lactation period. Chios had slightly higher average TS\% than Farafra (16.04 vs. 15.59\%), respectively. The SNF\% 
averaged 10.01 and $9.87 \%$ for Farafra and Chios milk. Protein content for Chios and Farafra milk differed significantly $(\mathrm{P}<0.01)$ and averaged 5.62 and $5.31 \%$, respectively. Ash in Farafra milk averaged $1.13 \%$ which was significantly $(\mathrm{P}<0.01)$ higher than $0.97 \%$ for Chios milk. Chios ewes had higher milk energy $(4.59 \mathrm{MJ} / \mathrm{kg})$ than Farafra $(4.34 \mathrm{MJ} / \mathrm{kg})$. The higher milk energy of Chios ewes was due to their higher fat percent than Farafra ewes. The differences between breeds were significant $(\mathrm{P}<0.01)$. These results agree with Economides (1986) who reported that the calorific value was $4.53 \mathrm{MJ} / \mathrm{kg}$ for Chios sheep's milk.

Table 2. $L S M \pm S E$ of factors affecting milk composition

\begin{tabular}{|c|c|c|c|c|c|c|c|}
\hline Items & $\mathbf{N}$ & Fat $\%$ & TS \% & SNF \% & Protein \% & Ash \% & $\begin{array}{c}\text { Milk } \\
\text { energy } \\
\text { (MJ/kg) }\end{array}$ \\
\hline G. mean & 228 & $5.22 \pm 1.22$ & $15.04 \pm 1.39$ & $9.82 \pm 1.19$ & $4.93 \pm 0.98$ & $1.07 \pm 0.25$ & $4.19 \pm 0.53$ \\
\hline Breed effec & & $* *$ & $* *$ & & $* *$ & $* *$ & $* *$ \\
\hline Farafra & 113 & $5.59 \pm 0.17$ & $15.59 \pm 0.19$ & $10.01 \pm 0.17$ & $5.31 \pm 0.14$ & $1.13 \pm 0.03$ & $4.34 \pm 0.07$ \\
\hline Chios & 115 & $6.17 \pm 0.16$ & $16.04 \pm 0.18$ & $9.87 \pm 0.15$ & $5.62 \pm 0.12$ & $0.97 \pm 0.03$ & $4.59 \pm 0.07$ \\
\hline $\begin{array}{l}\text { Lambing } \\
\text { season }\end{array}$ & & $* *$ & $* *$ & & $* *$ & $*$ & $* *$ \\
\hline February & 82 & $4.92 \pm 0.17^{\mathrm{b}}$ & $14.81 \pm 0.19^{c}$ & $9.89 \pm 0.16^{\mathrm{a}}$ & $4.16 \pm 0.13^{c}$ & $1.11 \pm 0.03^{\mathrm{a}}$ & $4.06 \pm 0.07^{\mathrm{b}}$ \\
\hline June & 70 & $5.65 \pm 0.20^{\mathrm{b}}$ & $15.68 \pm 0.22^{b}$ & $10.03 \pm 0.19^{\mathrm{a}}$ & $6.47 \pm 0.16^{\mathrm{a}}$ & $1.01 \pm 0.04^{\mathrm{a}}$ & $4.37 \pm 0.08^{b}$ \\
\hline October & 76 & $7.07 \pm 0.18^{\mathrm{a}}$ & $16.96 \pm 0.21^{\mathrm{a}}$ & $9.90 \pm 0.18^{\mathrm{a}}$ & $5.79 \pm 0.15^{\mathrm{b}}$ & $1.04 \pm 0.04^{\mathrm{a}}$ & $4.98 \pm 0.08^{\mathrm{a}}$ \\
\hline $\begin{array}{l}\text { Lactation } \\
\text { weeks }\end{array}$ & & $* *$ & $* *$ & $* *$ & $* *$ & $*$ & $* *$ \\
\hline W 2 & 36 & $3.05 \pm 0.20^{\mathrm{f}}$ & $13.24 \pm 0.23^{\mathrm{d}}$ & $10.19 \pm 0.20^{\mathrm{a}}$ & $4.12 \pm 0.16^{\mathrm{e}}$ & $1.20 \pm 0.04^{\mathrm{a}}$ & $3.25 \pm 0.09^{f}$ \\
\hline W 4 & 36 & $3.53 \pm 0.20^{\mathrm{f}}$ & $13.01 \pm 0.23^{\mathrm{d}}$ & $9.48 \pm 0.20^{\mathrm{a}}$ & $3.94 \pm 0.16^{\mathrm{e}}$ & $1.08 \pm 0.04^{\mathrm{a}}$ & $3.46 \pm 0.09^{\mathrm{f}}$ \\
\hline W 6 & 36 & $4.74 \pm 0.20^{\mathrm{e}}$ & $14.17 \pm 0.23^{\mathrm{cd}}$ & $9.43 \pm 0.20^{\mathrm{a}}$ & $4.32 \pm 0.16^{\mathrm{de}}$ & $1.06 \pm 0.04^{\mathrm{a}}$ & $3.98 \pm 0.09^{\mathrm{e}}$ \\
\hline W 8 & 36 & $5.51 \pm 0.20^{\mathrm{de}}$ & $15.05 \pm 0.23^{\mathrm{bc}}$ & $9.54 \pm 0.20^{\mathrm{a}}$ & $4.93 \pm 0.16^{\text {cde }}$ & $1.05 \pm 0.04^{\mathrm{a}}$ & $4.31 \pm 0.09^{\text {de }}$ \\
\hline W10 & 36 & $6.27 \pm 0.20^{\mathrm{cd}}$ & $16.13 \pm 0.23^{b}$ & $9.86 \pm 0.20^{\mathrm{a}}$ & $5.53 \pm 0.16^{\mathrm{abc}}$ & $1.03 \pm 0.04^{\mathrm{a}}$ & $4.64 \pm 0.09^{\mathrm{cd}}$ \\
\hline W12 & 31 & $7.62 \pm 0.22^{\mathrm{ab}}$ & $17.97 \pm 0.25^{\mathrm{a}}$ & $10.35 \pm 0.21^{\mathrm{a}}$ & $6.57 \pm 0.19^{\mathrm{a}}$ & $0.98 \pm 0.04^{\mathrm{a}}$ & $5.22 \pm 0.09^{\mathrm{ab}}$ \\
\hline W14 & 11 & $7.63 \pm 0.37^{\mathrm{abc}}$ & $17.75 \pm 0.42^{\mathrm{a}}$ & $10.12 \pm 0.36^{\mathrm{a}}$ & $6.73 \pm 0.30^{\mathrm{ab}}$ & $1.03 \pm 0.08^{\mathrm{a}}$ & $5.22 \pm 0.16^{\mathrm{abc}}$ \\
\hline W16 & 4 & $7.29 \pm 0.62^{\mathrm{a}}$ & $17.65 \pm 0.71^{\mathrm{a}}$ & $10.37 \pm 0.60^{\mathrm{a}}$ & $6.56 \pm 0.50^{\mathrm{ab}}$ & $1.06 \pm 0.13^{\mathrm{a}}$ & $5.07 \pm 0.27^{\mathrm{a}}$ \\
\hline W18 & 2 & $7.28 \pm 0.88^{\mathrm{bcd}}$ & $17.37 \pm 1.00^{\mathrm{b}}$ & $10.10 \pm 0.86^{\mathrm{a}}$ & $6.54 \pm 0.71^{\text {bcd }}$ & $0.99 \pm 0.18^{\mathrm{a}}$ & $5.07 \pm 0.38^{\mathrm{bcd}}$ \\
\hline
\end{tabular}

2. Lambing season: The autumn lambing ewes (October) had higher fat $\%, \mathrm{TS} \%$, $\mathrm{SNF} \%$, ash $\%$ and milk energy than both summer lambing (June) and spring season (February). Seasonal differences were significant $(\mathrm{P}<0.01)$ for $\mathrm{fat} \%, \mathrm{TS} \%$, protein $\%$ and milk energy, but significant $(\mathrm{P}<0.05)$ for ash $\%$ and were not significant for SNF\% (Table 2). These results may be attributed to the availability of fresh Egyptian clover and metabolic and endocrine changes related to the climate and the negative correlation between milk yield and fat\%. Sevi et al. (2004) reported similar results.

3. Lactation weeks: All parameters studied increased gradually throughout the 18 weeks of lactation. Fat was $3.05 \%$ in the $2^{\text {nd }}$ week and it reached $7.28 \%$ in the $18^{\text {th }}$ week, where the milk yield decreased by advancing in the lactation period. Also, TS was $13.24 \%$ in the $2^{\text {nd }}$ week and it reached $17.37 \%$ in the $18^{\text {th }}$ week.

4. Age and weight of ewe: Regression coefficients of the milk components percentages on age and weight of ewe at lambing were not significant, except regression coefficient of protein $\%$ on age of ewe was positively significant $(\mathrm{P}<0.01)$, and regression coefficients of ash $\%$ on weight of ewe was negatively significant 
$(\mathrm{P}<0.01)$. Hassan $(1995)$ reported that age of ewe had no significant effect on fat, TS and $\mathrm{SNF} \%$.

There were a negative and significant $(\mathrm{P}<0.01)$ correlations between milk yield with fat $\%$, TS $\%$, protein $\%$, ash $\%$ and milk energy, but not significant with $\mathrm{SNF} \%$. Fat $\%$ positively significant $(\mathrm{P}<0.01)$ correlated with $\mathrm{TS} \%$, protein $\%$ and milk energy. Similarly, Khalifa et al., (1994) found that significant correlation coefficient between milk fat and each of TS, SNF, protein and ash.

There were a positive and highly significant $(\mathrm{P}<0.01)$ correlations between TS\% and each of $\mathrm{SNF} \%$, protein $\%$ and milk energy, and negatively and highly significant $(\mathrm{P}<0.01)$ correlation coefficient $(\mathrm{r}=-.161)$ between TS\% and ash $\%$. Also, positive and significant $(\mathrm{P}<0.01)$ correlation coefficient was found between $\mathrm{SNF} \%$ and $\mathrm{ash} \%$. As well, positive and highly significant $(\mathrm{P}<0.01)$ correlation coefficient $(\mathrm{r}=0.683)$ was calculated between protein and milk energy.

\section{CONCLUSION}

The percentage of MBW ( 8 weeks) amounted $77.37 \%$ and $74.85 \%$ of the TMY for Farafra and Chios ewes, respectively. However, the percentage of MAW (marketable milk) amounted $22.63 \%$ and $25.15 \%$ from the TMY of Farafra and Chios ewes, respectively. These results indicated that most of the milk yield from local ewes (Farafra) was produced during suckling period ( 8 weeks). So, early weaning system was more suitable for Farafra ewes. The present figures for Farafra ewes are close to those of other native Egyptian breeds. Chios flock must be improved for milk production.

\section{REFERENCE}

Aboul-Naga, A. M., A. S. El-Shobokshy, I. F. Marie and M. A. Moustafa, 1981. Milk production from subtropical non-dairy sheep. 1. Ewe performance. J. Agric. Sci. (Comb.), 97: 297-301.

Al-Saigh, M. N. R. and A. A. D. Al-Khauzai, 1991. Effect of age and level of feeding on: 2- Milk of Arabi ewes. World Rev. of Anim. Prod. Vol. 26, No. 4: 37-42.

Al-Saigh, M. N. R. and A. A. D. Al-Khauzai, 1993. Effect of age of dam, level of feeding I $n$ late pregnancy and the changes in body weight on the performance of Arabi ewes and their lambs during lactation. Indiana J. of Anim. Sci., 63(1):5661.

APRI., 2000. Animal Production Research Institute, Sheep \& Goat Division allowances, Ministry of Agriculture, Egypt.

Duncan, D.B, 1955. Multiple range and multiple $F$ tests. Biometrics, 11: 1- 42.

Economides, S. 1986. Comparative studies of sheep and goats milk yield and composition and growth rate of lambs and kids. J. Agric. Sci., (Camb.):106, 477484.

FAO., 2004. FAOSTAT Database. www.FAO.org/faostat Database Results htm.

Galal E.S.E., F. Abdel Rasoul, M.R. Anous and I. Shaat, 2002. On-Station characterization of small ruminant breed in Egypt. ICARD, Aleppo, Syria.

Hassan, H. A., 1995. Effects of crossing and environmental factors on production and some constituents of milk in Ossimi and Saidi and their crosses with Chios. Small Rumin. Res., 18: 165-172. 
Khalifa, R. M., S. A. Mokhtar, M. A. Yassen and F. Z. Swidan, 1994. Comparative study between Sinai and Rahmani sheep. 2. performance of ewes during pregnancy and lactation; birth and weaning weights of lambs. Egyptian J. Anim. Prod. Vol. 31, Supplement, Nov., pp. 491-511.

Mousa, M.T., 1991. Effect of crossing Ossimi, Awassi and Chios sheep on some production traits. Ph.D. Thesis, Fac. Of Agric., Assiut Univ., Egypt.

SAS, 1995. SAS User's guide: Statistics, SAS Institute Inc., Cary, NC.

Sevi, A., M. Albenzio, R. Marino, A. Santillo and A. Muscio, 2004. Effects of lambing season and stage of lactation on ewe milk quality. Small Rumin. Res. (51): 251-259. 


\section{إنتاج اللبن و مكوناته لأغنام الكيوس والفرافرة تحت الظروف المصرية الثبه حارة}

\section{حاتم حمدون'، محمد نصرت عبد العاطى"، محمد زينهم"، فاروق علامَّ}

1 - معهة الدراسات و البحوث البيئية، جامعة المنوفية, فرع السادات، r - قسم الإتتاج الحيواني والدواجن،

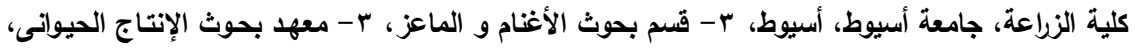

أجريت هذه الدراسة فى مزرعة تجارب الإنتاج الحبوانى بملوى التابعة لمعهد بحوث الإنتاج الحيوانى. تم

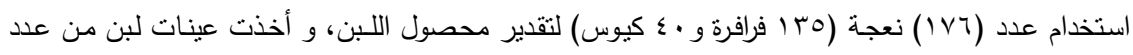

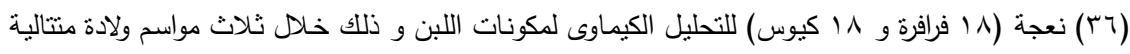

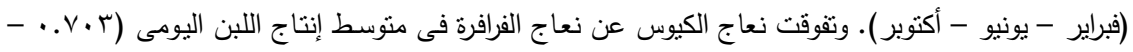

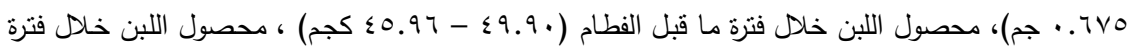

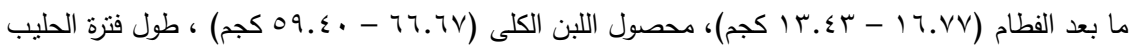

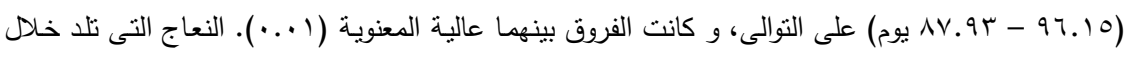

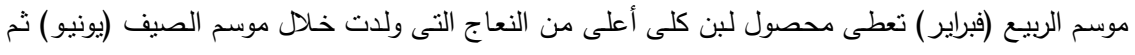

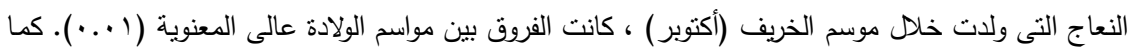

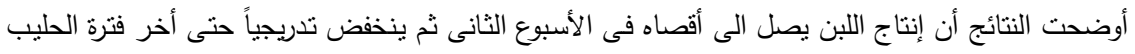

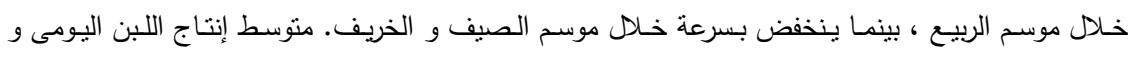

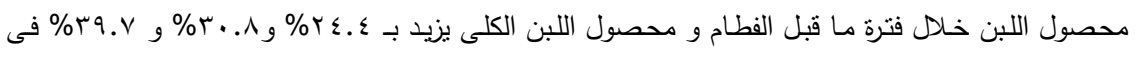

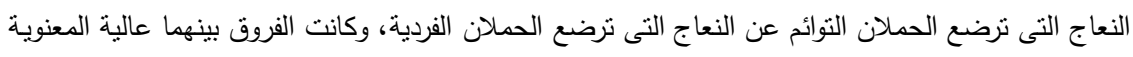

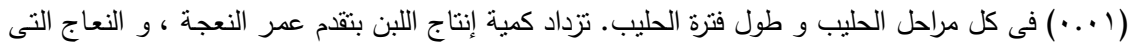

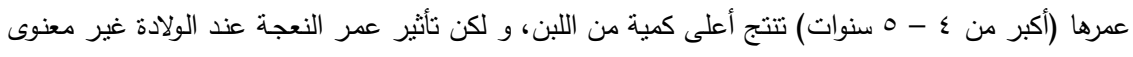

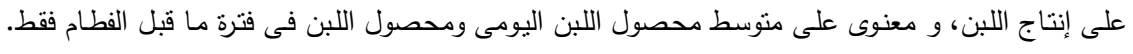

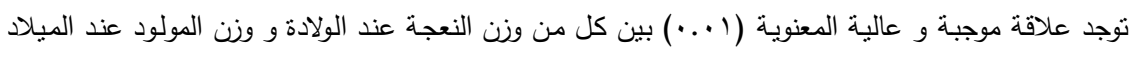

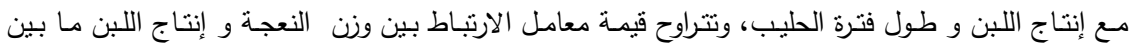

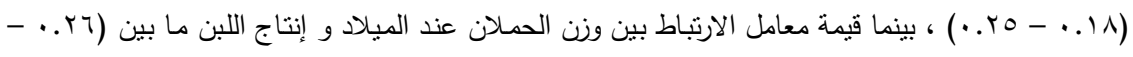

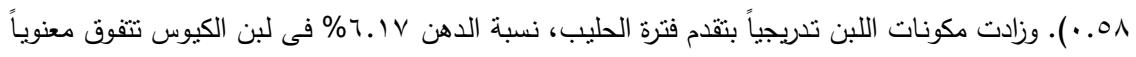

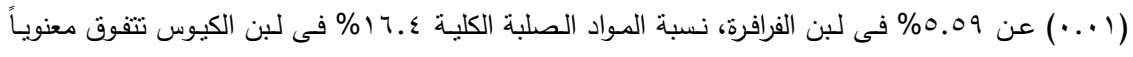

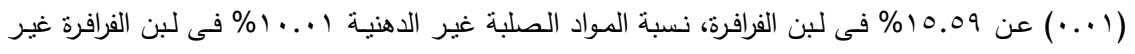

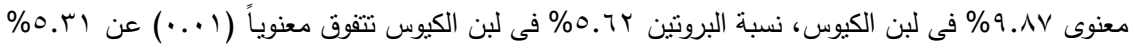

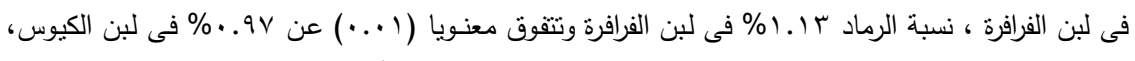

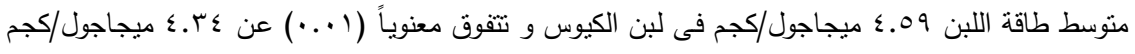


فى لبن الفرافرة. أما موسم حليب الخريف (أكتوبر) كان عالى المعنوية (1 ...) فى نسبة الدهن ونسبة المواد الصلبة الكلية ونسبة المواد الصلبة غير الدهنية ونسبة الرماد وطاقة اللبن عن موسم حليب الصيف (يونيو) وموسم حليب الربيع (فبراير)، الفروق الموسمية تكون معنوية مع نسبة الدهن ونسبة المواد الصلبة الكلية ونسبة البروتين ونسبة الرماد وطاقة اللبن، وغير معنوية مع نسبة المواد الصلبة غير دهنية. 